\title{
壁式構造における，接合部パネルのせん断応力に関する研究 SHEAR STRESSES OF BEAM AND BEARING-WALL CONNECTION JOINTS FOR BOX-FRAMED BUILDINGS .
}

\author{
松井源 吾*, 楊 振 亮** \\ Gengo MATSUI and Jenn Lian YANG
}

\begin{abstract}
This Paper is concerned with the shear stresses in beam and bearing-wall connection joints for box-framed reinforced concrete buildings. For these buildings, the A.I.J. code specifies the ammount of horizontal lengths of walls per unit area of each floor. From this specification it sometimes may follow that a beam is designed to have smaller depth for larger opening in a wall.

By employing the hyperbolic functions to represent the normal stresses due to bending moments from a beam and a bearing-wall, a theoretical solution for the shear stresses for the connection joint is presented. Its validity is confirmed by conducting the photo-elastic experiments.
\end{abstract}

Keywords : box-framed buildings, shear stresses, photo-elasticity 壁式鉄筋コンクリート造, せん断応力度, 光弾性

序

壁式鉄筋コンクリート造（以下，壁式構造という) に おいては，壁のせん断耐力を重視して壁量（床面積に対 する壁厚と壁長さ) が決められている。そのため, 南側 など開口面積を大きくするため, 梁せいを小さくする場 合が多い。梁せいは $45 \mathrm{~cm}$ 以上としか決められていな い。これによって, 壁梁と耐力壁の接合部パネルの面積 が小さくなり, 地震時にせん断态力が増大し, 検討の必 要が生じてくる。

筆者は先に，窓の配置を変えることによって，この応 力の増大を避けることができることを指摘した洋1。し かし、アパートなどでは, 各階の空の位置は変えられな いのが普通である。梁および接合部のせん断応力を増大 させないために，ある程度の梁せいは必要なのである。 本論文では,

1）壁梁部分を横に長い帯板として考え, 耐力壁から曲 げとせん断をうける

2) 耐力壁部分を縦に長い带板として考え, 壁梁から曲 げとせん断をうける

として, それぞれのせん断応力の解を求め, パネル部の 最大せん断态力について検討を行ったものである。 前論文では，柱からの曲げを簡単に三角形分布とした ため, 光弾性実験とかなりの誤差があった。

その後, 梁の剛域の研究 ${ }^{\mathrm{i}: 22} に$ 際して, パネル部と梁, または柱の境界線上の垂直応力は，双曲線関数と一次関
数の組合せで近似できることを確かめている。

本論文では，この結果を用い，幅の広い部材では双曲 線関数だけで近似できることを確かめ; 曲げ応力を双曲 線関数的分布として解を求めている。 また, 光弾性実験を行い,この解を確かめている。

\section{1. 帯板の応力}

通常, 壁式構造では, 耐力壁, 壁梁が同一の厚さであ ることが多い。それで厚さを一定とした二次元弾性論に おいて，平面応力として扱うことにする。図一1のよう な幅 $2 c て ゙, 2 l$ を周期とする荷重を受ける帯板の解を 考える。

$$
\begin{gathered}
\text { 二次元弾性論における横田の一般式 }{ }^{i z 3)} \text { は } \\
\sigma_{x}+\sigma_{y}=2 R_{e}[g(z)] \\
\sigma_{x}-\sigma_{y}-2 i \tau_{x y}=2 i y g^{\prime}(\dot{z})+h(z)
\end{gathered}
$$

で表される。ここに $g(z), h(z)$ は複素関数, $g^{\prime}=d g / d z$,

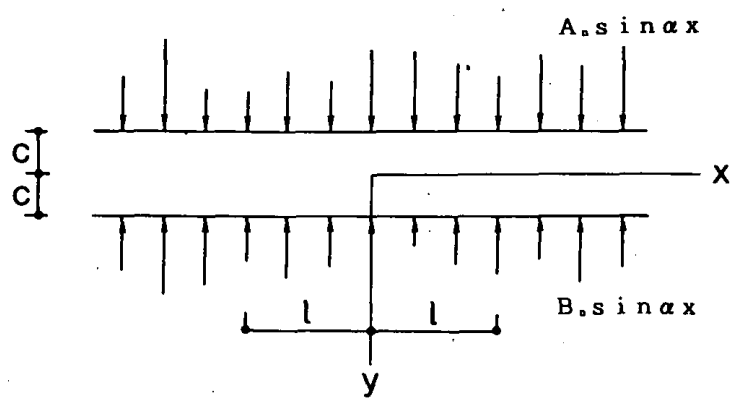

图一1 幅 $2 c$ の帯板と外力
* 早稲田大学 教授.工博

** 楊構造事務所 (台湾) ·工修
Prof., Waseda Univ., Dr. Eng.

Yang Structual Design Office (Taiwan), M. Eng. 
$R_{e}$ は実部を意味する。

この場合の解として, 複素関数を次のように選ぶ。

$$
\begin{aligned}
g(z)= & \alpha\left(i c_{3} \cos \alpha z+c_{4} \sin \alpha z\right) \\
h(z)= & 2 \alpha^{2}\left(c_{1} \sin \alpha z+i c_{2} \cos \alpha z\right) \\
& +2 \alpha\left(i c_{3} \cos \alpha z+c_{4} \sin \alpha z\right)
\end{aligned}
$$

ただし $\alpha=n \pi / l$

これらより

$2 R_{e}[g(z)]=2 \alpha \sin \alpha x\left\{c_{3} \sinh \alpha y+c_{4} \cosh \alpha y\right\}$

$R_{e}\left[2 i y g^{\prime}(z)+h(z)\right]=2 \alpha \sin \alpha x$

$\cdot\left\{a\left(c_{1} \cosh \alpha y+c_{2} \sinh \alpha y\right)\right.$

$+c_{3}(\sinh \alpha y+\alpha y \cosh \alpha y)$

$I_{m}\left[2 i y g^{\prime}(z)+h(z)\right]=2 \alpha \cos \alpha x$

$\left.+c_{4}(\cosh \alpha y+\alpha y \sinh \alpha y)\right\}$

- $\left\{\alpha\left(c_{1} \sinh \alpha y+c_{2} \cosh \alpha y\right)\right.$

$+c_{3}(\cosh \alpha y+\alpha y \sinh \alpha y)$ $\left.+c_{4}(\sinh \alpha y+\alpha y \cosh \alpha y)\right\}$

が得られる。ただし $I_{m}$ は虚部を意味する。 境界条件を次のようにする。

$$
\begin{array}{lll}
y=+c に て & \tau_{x y}=0 & \sigma_{y}=-B_{n} \sin \alpha x \\
y=-c \text { にて } & \tau_{x y}=0 & \sigma_{y}=-A_{n} \sin \alpha x
\end{array}
$$

これらの条件より $c_{1} \sim c_{4}$ が求まる。

すなわち

$$
\begin{aligned}
& c_{1}=\frac{A_{n}+B_{n}}{\alpha^{2}} \frac{\sinh \alpha c+\alpha c \cosh \alpha c}{\sinh 2 \alpha c+2 \alpha c} \\
& c_{2}=-\frac{A_{n}+B_{n}}{\alpha^{2}} \frac{\cosh \alpha c+\alpha c \sinh \alpha c}{\sinh 2 \alpha c-2 \alpha c} \\
& c_{3}=\frac{A_{n}-B_{n}}{\alpha^{2}} \frac{\alpha \cosh \alpha c}{\sinh 2 \alpha c-2 \alpha c} \\
& c_{4}=-\frac{A_{n}+B_{n}}{\alpha^{2}} \frac{\alpha \sinh \alpha c}{\sinh 2 \alpha c+2 \alpha c}
\end{aligned}
$$

これより垂直応力 $\sigma_{x}$ は次式となる。

$$
\begin{aligned}
\sigma_{x}= & \left(A_{n}+B_{n}\right) \frac{(\alpha c \cosh \alpha c-\sinh \alpha c) \cosh \alpha y-\alpha y \sinh \alpha y \sinh \alpha c}{\sinh 2 \alpha c+2 \alpha c} \sin \alpha x \\
& -\left(A_{n}-B_{n}\right) \frac{(\alpha c \sinh \alpha c-\cosh \alpha c) \sinh \alpha y-\alpha y \cosh \alpha y \cosh \alpha c}{\sinh 2 \alpha c-2 \alpha c} \sin \alpha x
\end{aligned}
$$

またせん断応力は

$$
\begin{aligned}
\tau_{x y}= & -\left(A_{n}+B_{n}\right) \frac{\alpha c \cosh \alpha c \sinh \alpha y-\alpha y \cosh \alpha y \sinh \alpha c}{\sinh 2 \alpha c+2 \alpha c} \cos \alpha x \\
& +\left(A_{n}-B_{n}\right) \frac{\alpha c \sinh \alpha c \cosh \alpha y-\alpha y \sinh \alpha y \cosh \alpha c}{\sinh 2 \alpha c-2 \alpha c} \cos \alpha x
\end{aligned}
$$

2. 接合部パネルと, 梁, 柱との境界線上の垂直応力

この線上では端に応力集中が起こるので, 曲げ応力は 三角形分布ではない。

写真一1, 2 は梁成 $2 \mathrm{~cm}$, 柱幅 $4 \mathrm{~cm}$ の接合部の純曲げ の光弾性等色線である。これによる接合部パネルと梁と の境界線上の垂直応力を求めると図一2における黒丸の ようになる。

この垂直応力の分布に対して, 次式のように双曲線関 数と一次式の組合せを考える。

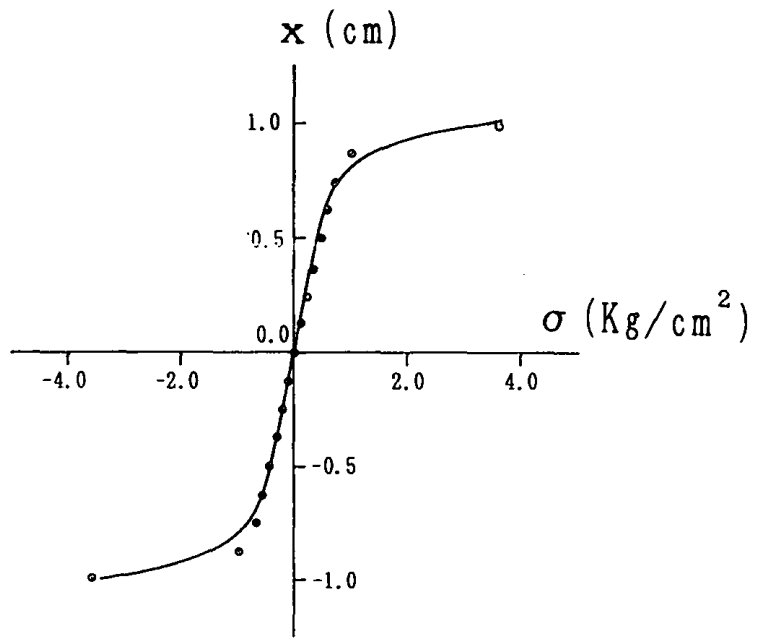

図一2 梁と接合部パネル境界線の垂直応力

$$
\sigma_{y}=-\frac{p}{1+k}\left(\frac{1}{\sinh \gamma} \sinh \frac{\gamma}{c} x+\frac{k}{c} x\right)
$$

ここに $p$ は縁応力, $2 c$ は梁せいである。 この式に $\gamma=10, k=0.3$ を入れると, 図一2 の曲線と なり光弾性結果の黒丸と近似している。

材の幅が大きく, 材長の短い材の場合, 光弾性実験で は縞数が少なく，誤差が大きい。そのため細長い材の分 布を（3）式として与え, 計算よりパネル部との境界線 上の応力を求める。

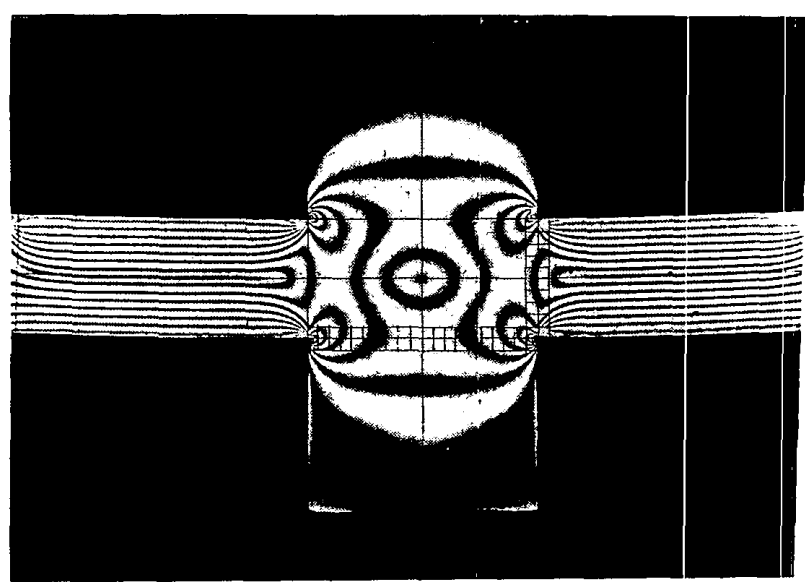

写真一1 梁柱接合部の光弾性等色線 (暗視野) 梁せい $2 \mathrm{~cm}$, 柱幅 $4 \mathrm{~cm}$, 純曲 
図一3のように柱を縦長の帯板と考え，これに梁から 曲げ応力を受けるものとする。梁からの曲げ応力は上記 の (3) 式の形の分布とする。(1) 式にて $c \rightarrow a, l$ $\rightarrow(h / 2+c)$ とし, $x=c$ とすると, 柱と接合部パネル の境界線上の垂直応力が求まる。図一4における曲線が

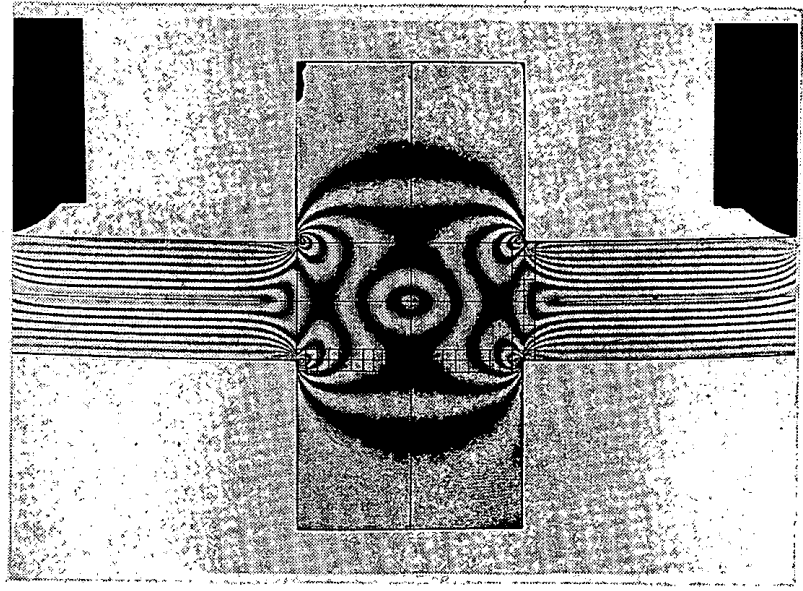

写真一2 梁柱接合部の光弾性等色線 (明視野)

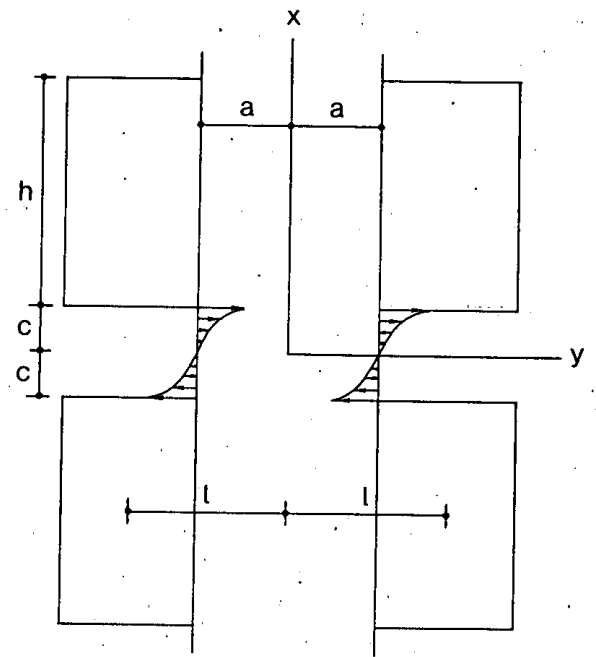

図一3柱を縦長の帯板とし，梁からの曲げ応力を加える場合

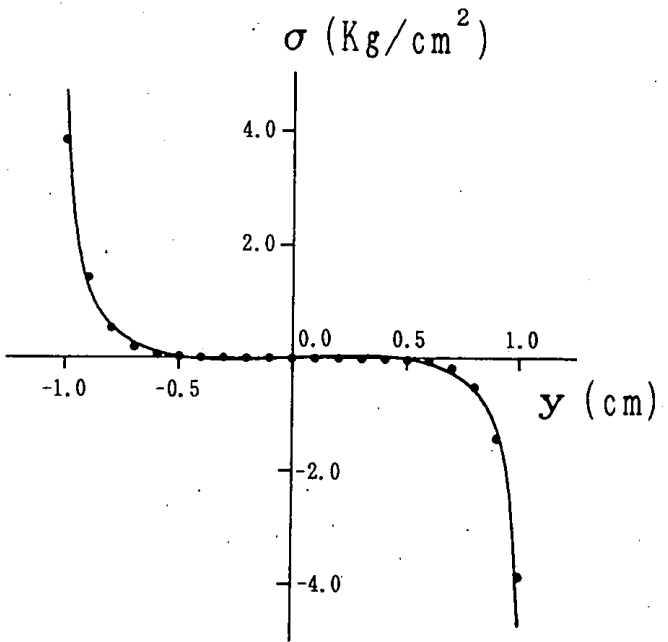

図一4 柱と接合部パネルの境界線上の垂直応力 $(a / 1=0.56, c / 1=0.31$ の場合)
その値を示している。( 3 ) 式にて $c \rightarrow a, k=0$ とした 次式

$$
\sigma_{x}=-p \frac{\sinh \frac{10}{a} y}{\sinh 10}
$$

が図一 4 における黒丸で，曲線とよく一致している。

壁式構造の場合, 耐力壁は幅为大きく, 梁せいが小さ い場合が多い。壁柱からの梁への曲げ応力は (4) 式と してよいであろう。

\section{3. 梁が等断面の場合のパネル部のせん断応力}

梁が等断面の場合, 梁を横長の帯板と考え，柱からの 曲げとせん断を外力として加え解を求める。

耐力壁の断面，間隔同一の場合とする。

空の間の柱のせん断力を $Q$, 反曲点を中央とすると, 柱の上下端に

$$
M=Q h / 2
$$

の曲げモーメントが生ずる。その応力分布を（4）式と 仮定すると, 縁応力 $(p)$ と曲げモーメントの関係は

$$
M=2 \int_{0}^{a} \sigma_{y} \cdot x \cdot d x
$$

より求まる。

$$
p=-\frac{50}{9} \cdot \frac{M}{a^{2}}=-\frac{25}{9} \cdot \frac{Q h}{a^{2}}
$$

この荷重は $2 l$ を周期とするから,フーリ工級数に展 開できる。(1), (2) 式における $A_{n}, B_{n}$ は

$$
\begin{aligned}
B_{n} & =\left(-A_{n}\right)=\frac{2}{l} \int_{0}^{a}-p \frac{1}{\sinh 10} \sinh \frac{10}{a} x \cdot \sin \alpha x d x \\
& =-\frac{2}{l} p \frac{1}{\left(10 / a+\alpha^{2} a / 10\right)}\left(\sin \alpha a-\frac{a}{10} \alpha \cos \alpha a\right)
\end{aligned}
$$

これを（2）式に入れれば，横に長い帯板の曲げによ るせん断応力が求まる。

このほか，柱にはせん断力 Qがあるが，これによる せん断応力は $l$ が $a$ に比べてあまり大きくなければ等 分布と考えてよいであろう。

梁の中心線上のせん断応力は

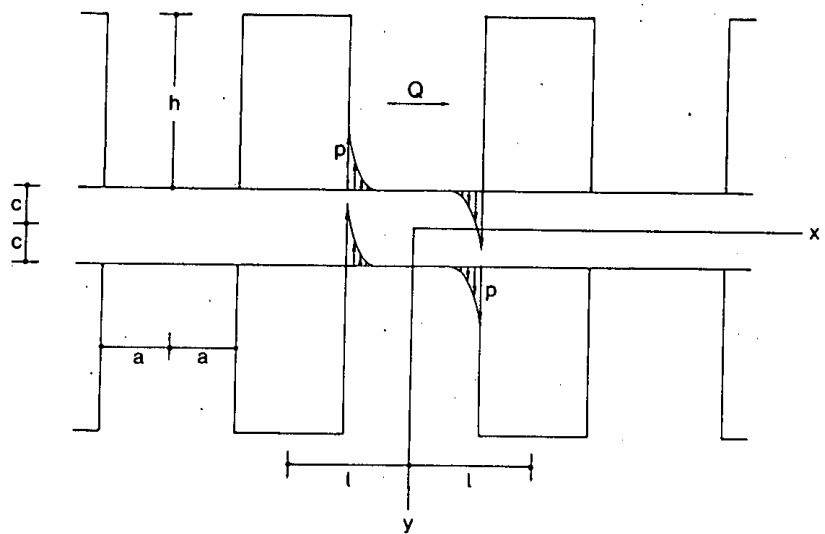

図一5“梁を帯板とし，柱からの曲げとせん断を加える場合 


$$
\begin{aligned}
\left(\tau_{x y}\right)_{y=0}= & \frac{100}{9} \frac{Q h}{a^{2} l} \sum_{n=1,2,3 \cdots}^{\infty} \frac{1}{\left(10 / a+\alpha^{2} a / 10\right)} \\
& \cdot\left(\sin \alpha a-\frac{a}{10} \alpha \cos \alpha a\right) \\
& \times \frac{\alpha c \sin \alpha c}{\sinh 2 \alpha c-2 \alpha c} \cos \alpha x-\frac{Q}{2 l}
\end{aligned}
$$

\section{となる。}

縦長の長方形開口, 長辺と短辺の比が 1.5 の場合につ いての計算例を図一6に示す。開口が正方形の場合 ${ }^{ \pm 11} に$ 比べて，せん断応力は一般的に大となる。

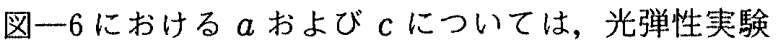
の試験体（図一7）に対応するものと，その中間的な值 について計算している。計算値 6 例のうち 2 例はパネル 部で $1.5 \tau_{0}$ を超えている。 $\tau_{0}$ は壁の平均せん断応力であ る。現行の壁式構造の設計では壁量規定を重視し, 耐力 壁の平均せん断応力度に基づく応力算定が基本となって いる。以上のことにより，神を規準とすることにした。 壁のせん断応力分布を放物線とし, 壁の最大せん断応力 を $1.5 \tau_{0}$ とした。計算例では, 梁はほとんど $1.5 \tau_{0}$ を超 えていて，せん断補強が必要となる。梁はスターラップ による補強が可能であるが，パネル部のせん断補強につ いては適当な方法が示されていない。許容応力度以内に すべきであろう。なお，この解では梁の上下の階の柱の せん断力を同一とした。実際は当然違うわけで，上下の

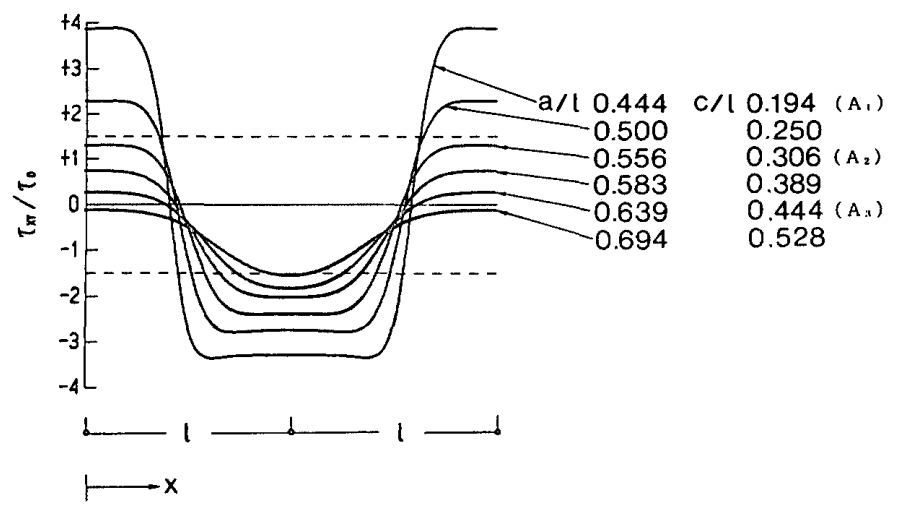

图一6 梁中心線上のせん断応力 (辺比 1.5 の縌長開口の場合)

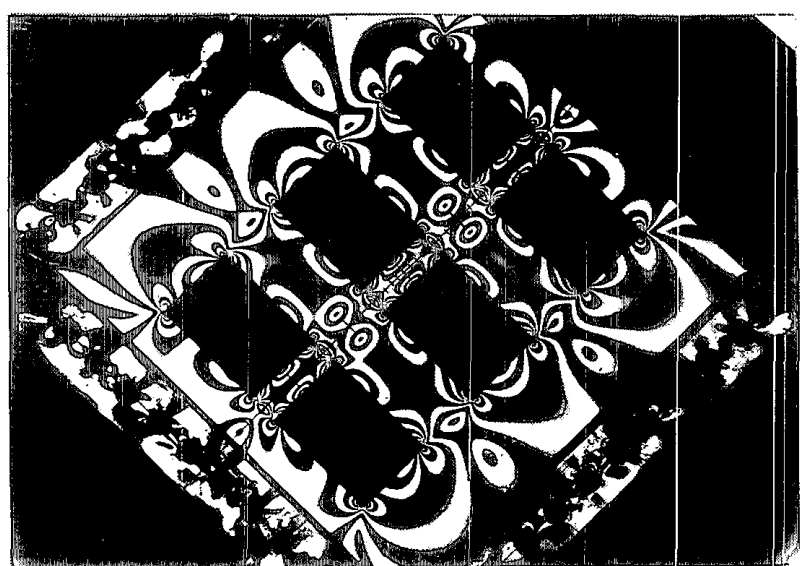

$A_{1}$

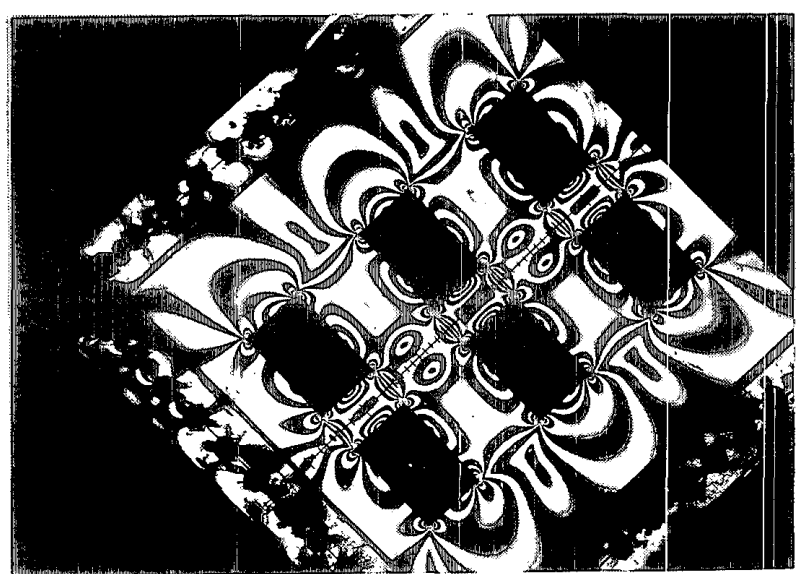

$A_{2}$

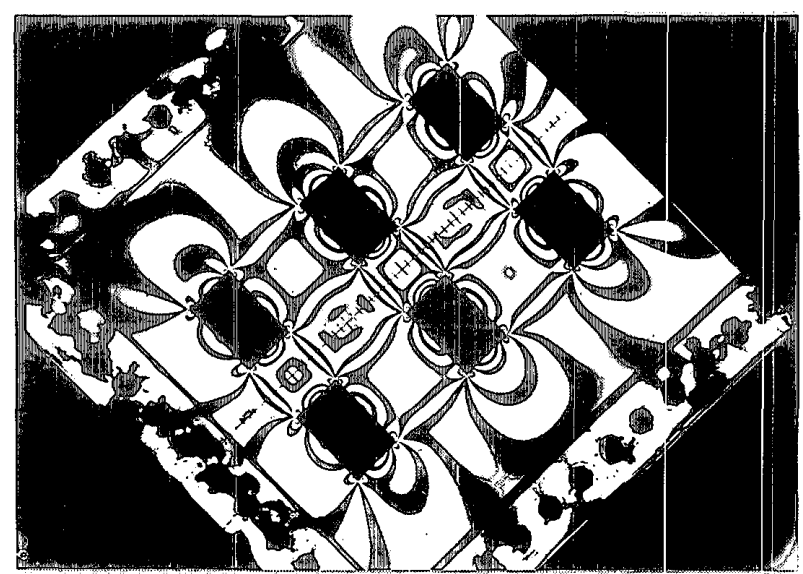

$\mathrm{A}_{3}$

写真一3 梁せい一定の場合の純せん断の光弾性等色線 (暗視野)

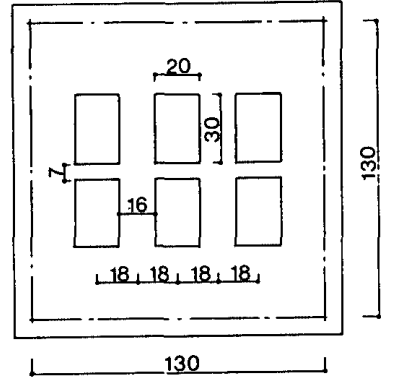

$A_{1}$

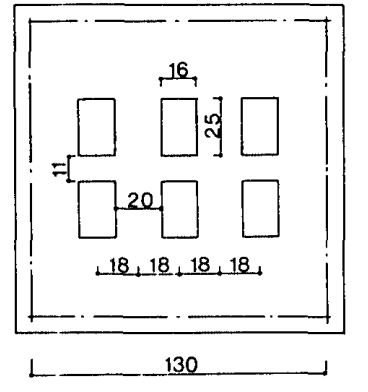

$\mathrm{A}_{2}$

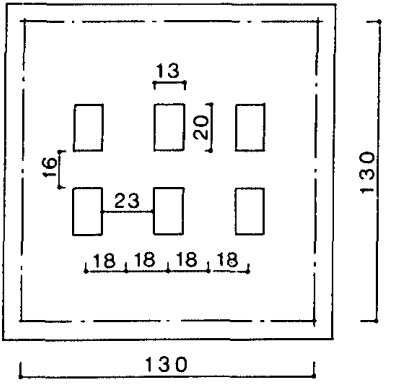

$\mathrm{A}_{3}$

図一7梁せい一定の場合の光弾性試験片 


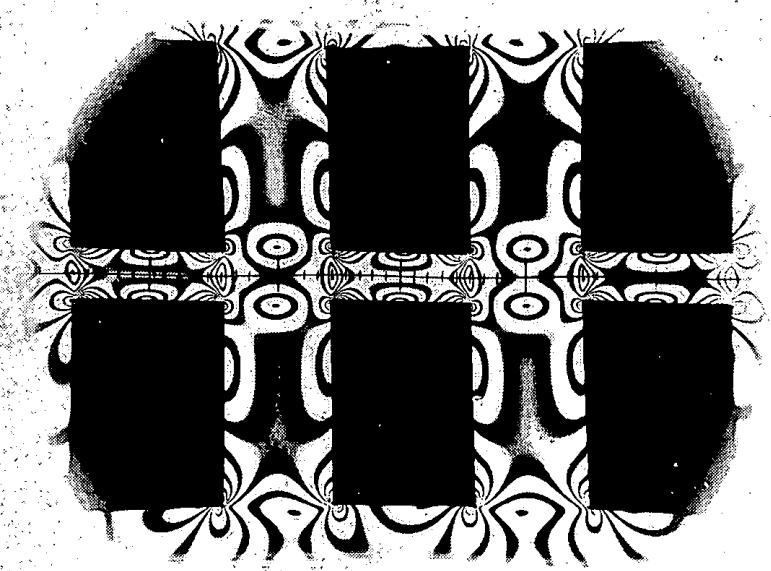

$A_{1}$

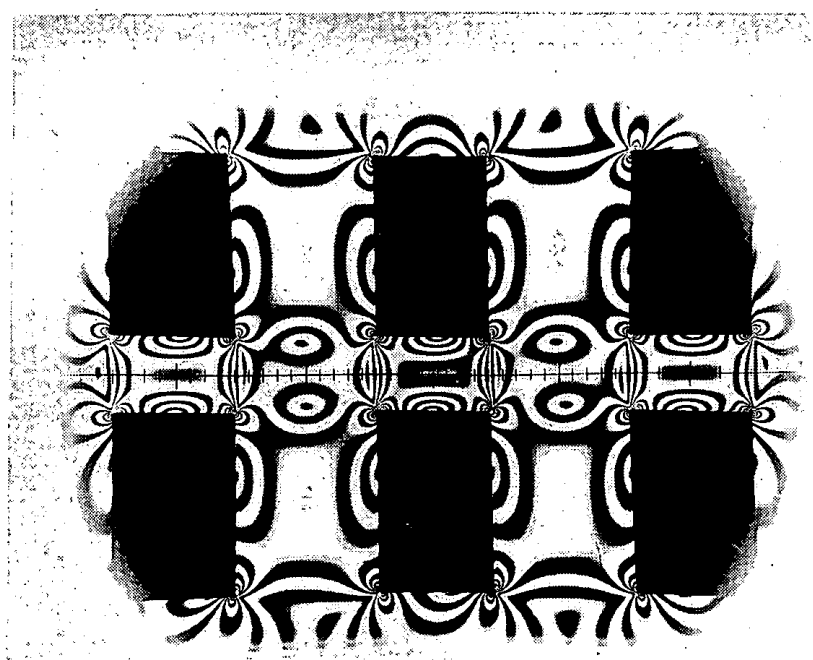

$\mathrm{A}_{2}$

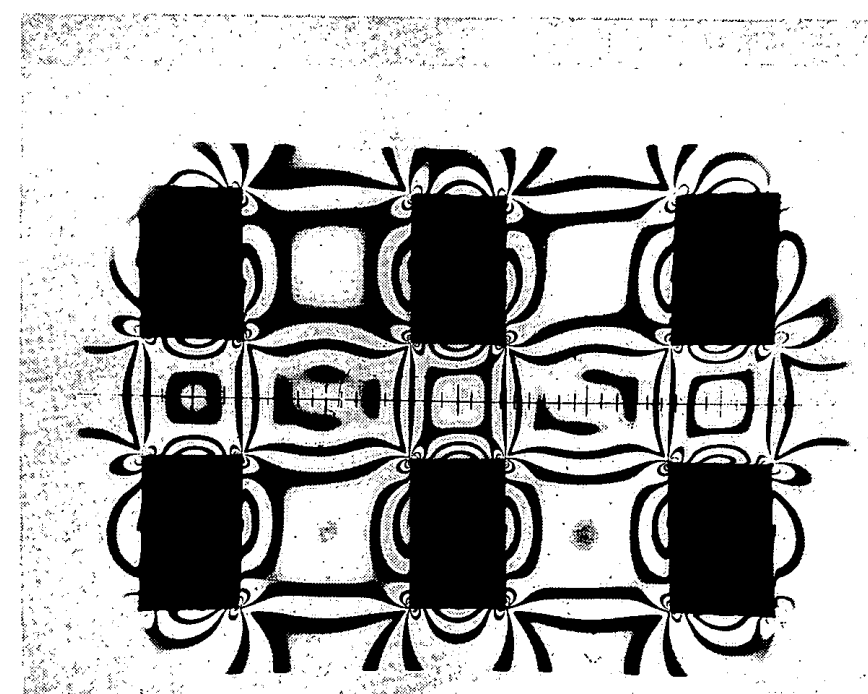

$\mathrm{A}_{3}$

写真一4 同拡大
$A_{1}$

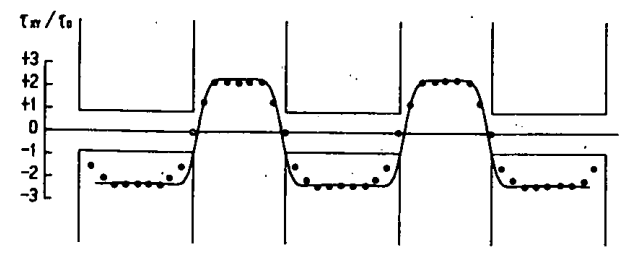

$\mathrm{A}_{2}$

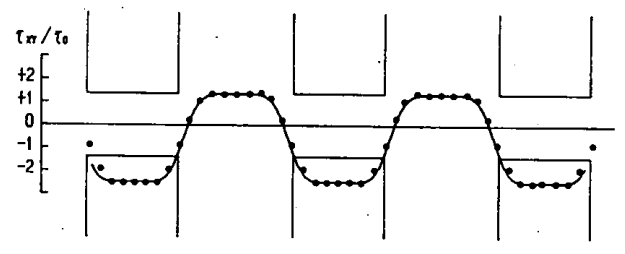

$\mathrm{A}_{3}$

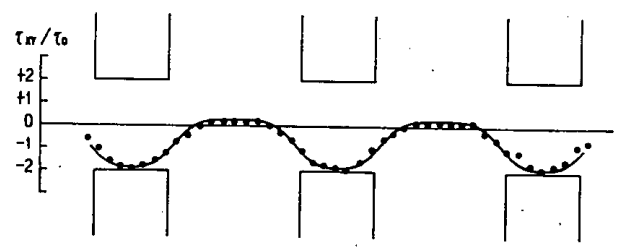

図一8 梁せい一定の場合の梁中心線上のせん断応力 試験片は厚さ $6 \mathrm{~mm}$ の DAP 板で，その四辺を アクリライト板の染で両側から挟み, この枠の四 隅はピン接合である。これを $45^{\circ}$ 傾け，上下に押 し, 左右に引張って，せん断を加えた。

その光弾性等色線 (暗視野) が写真一3で, 部 分的拡大が写真一 4 である。

図一8に梁中心線上のせん断応力を示した。曲 線は理諭值, 黒丸が光弾性実験值であるが, かな りよく合っている。試験片 $A_{1}$ の場合は柱の反曲 点が梁より $h / 3$ の所にあるため, $(6)$ 式の $h$ の 代わりに $2 h / 3$ としている。

パネル部の $\sigma_{y}$ の合計は

$$
2 \int_{0}^{a} \sigma_{y} d x=\frac{10}{9} \frac{M}{a}=\frac{10}{9} \tau_{0} h
$$

となるので, 最大応力の略算式として，

$$
\tau_{\max } \doteqdot 1.5\left\{\frac{5 h}{9 c}-\frac{a}{l}\left(\frac{h}{2 c}+1\right)\right\} \tau_{0}
$$

が得られる。

この式に悹の大きい $A_{1}$ の場合を入れると 2.19 $\tau_{0}$ となる。精算值は $2.41 \tau_{0}$ であるから $9 \%$ の誤 差である。しかし，この式は窓の小さい場合は誤 差が大きい。

柱からの曲げ応力の分布を三角形分布としたと きは

$$
2 \int_{0}^{a} \sigma_{y} d x=\frac{3}{2} \frac{M}{a}
$$

となり, 最大応力の略算式は

$$
\tau_{\max } \doteqdot 1.5\left\{\frac{3}{4} \frac{h}{c}-\frac{a}{l}\left(\frac{h}{2 c}+1\right)\right\} \tau_{0}
$$

この解の検討のため, 光弾性実験を行った。

図一7に試験片の寸法を示す。 
となり，双曲線分布とした時の第 1 項の係数 $5 / 9$ が $3 / 4$ となり，かなり大きい値となる。

$A_{1}$ の場合, 三角形分布とすると, $\tau_{\max }=3.86 \tau_{0}$ となり, 精算值 $2.41 \tau_{0}$ の $60 \%$ 増しとなり実状に合わない。

\section{4. 柱が等断面の場合のパネル部のせん断応力}

公団アパート南面架構によくみられる, 耐力壁が通っ ていて左右の梁の梁せいが違う場合である。この場合は, 幅 $2 a$ の柱を帯板と考え, 左右の梁から曲げとせん断を 受けるものとする（図一9）。

境界条件として

$$
\begin{gathered}
y=+a \text { にて } \tau_{x y}=0 \quad \sigma_{y}=-B_{n} \sin \alpha x \\
y=-a \text { にて } \tau_{x y}=0 \quad \sigma_{y}=-A_{n} \sin \alpha(x+d) \\
(\alpha=n \pi / h)
\end{gathered}
$$

これらの条件より，前と同様に $c_{1} \sim c_{4}$ を求め，せ九断 応力を計算すると次式となる。

$$
\tau_{x y}=-\left\{B_{n} \cos \alpha x+A_{n} \cos \alpha(x+d)\right\}
$$

. $\alpha a \cosh \alpha a \sinh \alpha y-\alpha y \cosh \alpha y \sinh \alpha a$ $\sinh 2 \alpha a+2 \alpha a$

$+\left\{A_{n} \cos \alpha(x+d)-B_{n} \cos \alpha x\right\}$

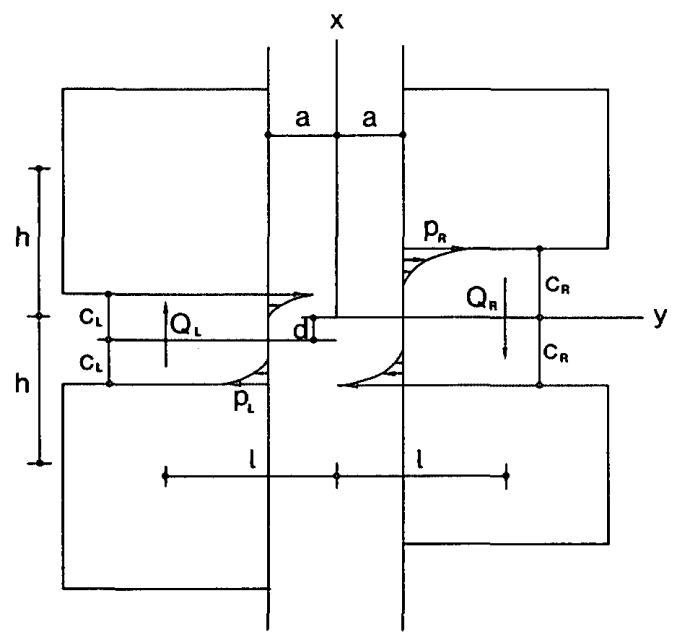

図一9 柱を縦長の帯板とし，左右のせいの違う梁からの曲げと せん断を加える場合

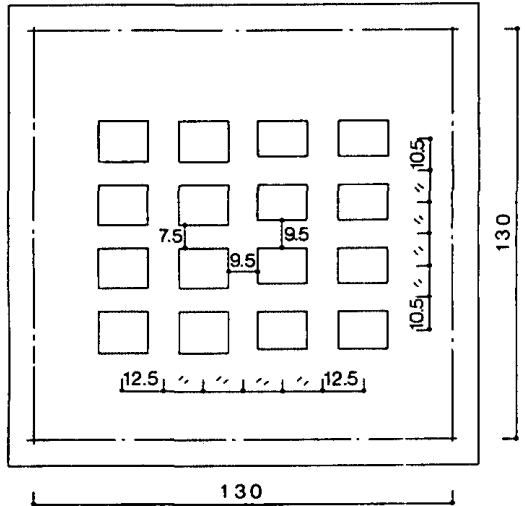

$\mathrm{B}_{1}$

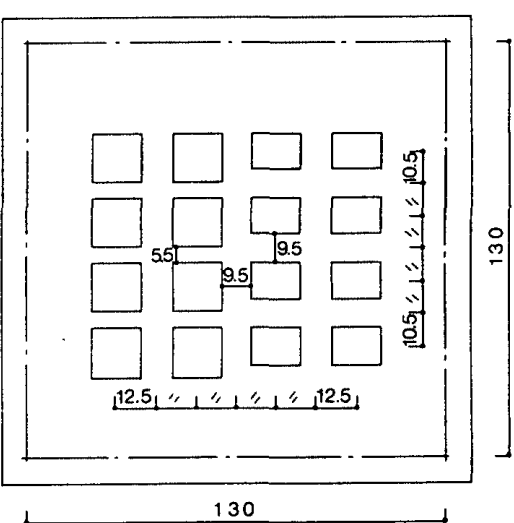

$\mathrm{B}_{2}$ $\alpha a \sinh \alpha a \cosh \alpha y-\alpha y \sinh \alpha y \cosh \alpha a$ $\sinh 2 \alpha a-2 \alpha a$

応力の分布形は前節と同様に一次の項を省略し, 双曲 線関数の分布とすると，

$$
\begin{aligned}
B_{n}= & -\frac{2}{h} p_{R} \frac{1}{10 / C_{R}+\alpha^{2} C_{R} / 10} \\
& \cdot\left(\sin \alpha C_{R}-\frac{C_{R}}{10} \alpha \cos \alpha C_{R}\right) \\
A_{n}= & +\frac{2}{h} p_{L} \frac{1}{10 / C_{L}+\alpha^{2} C_{L} / 10} \\
& \cdot\left(\sin \alpha C_{L}-\frac{C_{L}}{10} \alpha \cos \alpha C_{L}\right)
\end{aligned}
$$

縁応力も前と同様に

$$
p_{R}=\frac{50}{9} \cdot \frac{Q_{R}(l-a)}{C_{R}^{2}}, \quad p_{L}=\frac{50}{9} \cdot \frac{Q_{L}(l-a)}{C_{L}^{2}}
$$

これらにより，柱中心線上のせん断応力は

$$
\begin{aligned}
\left(\tau_{x y}\right)_{y=0}= & \left\{\frac{100}{9} \cdot \frac{Q_{R}(l-a)}{h C_{R}^{2}} \sum \frac{1}{10 / C_{R}+\alpha^{2} C_{R} / 10}\right. \\
& \cdot\left(\sin \alpha C_{R}-\frac{C_{R}}{10} \alpha \cos \alpha C_{R}\right) \cos \alpha x \\
& +\frac{100}{9} \cdot \frac{Q_{L}(l-a)}{h C_{L}^{2}} \sum \frac{1}{10 / C_{L}+\alpha^{2} C_{L} / 10} \\
& \left.\cdot\left(\sin \alpha C_{L}-\frac{C_{L}}{10} \alpha \cos \alpha C_{L}\right) \cos \alpha(x+d)\right\} \\
& \times \frac{\alpha a \sinh \alpha a}{\sinh 2 \alpha a-2 \alpha a}-\frac{Q_{R}+Q_{L}}{4 h} \cdots \cdots(7)
\end{aligned}
$$

となる。

この解の検討のため, 光弾性実験を行った。

図一10 は試験片の寸法である。前と同様にせん断力 を加えた等色線写真が写真一5，6である。

図一11は柱中心線上のせん断応力で曲線は（7）式

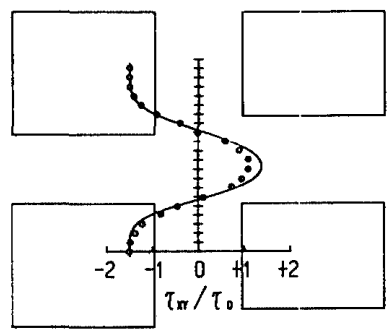

$\mathrm{B}_{1}$

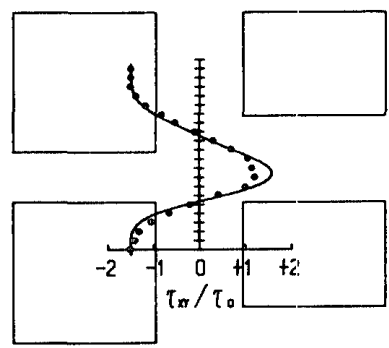

$\mathrm{B}_{2}$

図一11左右の梁せいが異 なる場合の柱中心 線上のせん断応力 


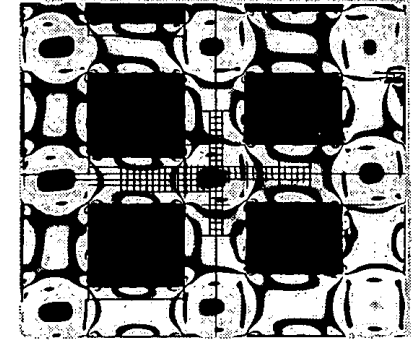

(暗視野)

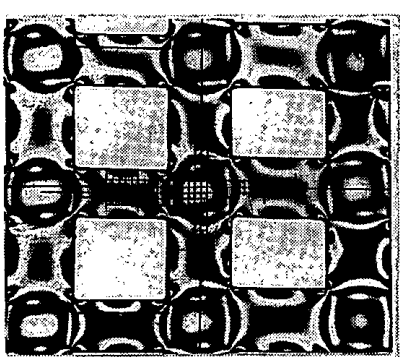

(明視野)
写真一5 左右の梁せいが異なる場合の純せん断の光弾性等色線 $\left(B_{1}\right)$

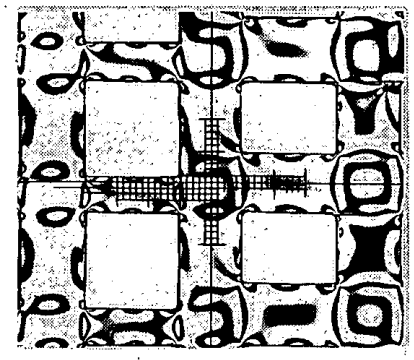

(明視野)

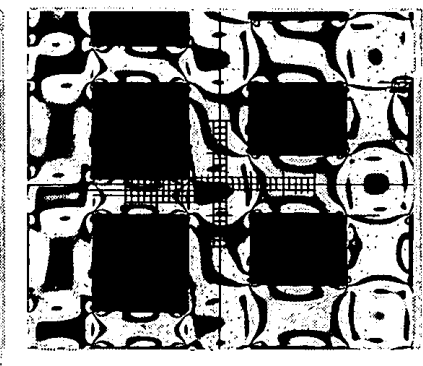

(暗視野)
写真一 6 左右の梁せいが異なる場合の純せん断の光弾性等色線 $\left(\mathrm{B}_{2}\right)$

によるものであり，黒丸が光弾性結果である。 パネル部の $\sigma_{y}$ の合計は

$$
\int_{0}^{C_{R}} \sigma_{y} d x+\int_{0}^{C_{L}} \sigma_{y} d x=\frac{5(l-a)}{9}\left(\frac{Q_{R}}{C_{R}}+\frac{Q_{L}}{C_{L}}\right)
$$

となり,また

$$
\tau_{0}=\frac{1}{2 a}\left(\frac{Q_{R}+Q_{L}}{2} \cdot \frac{l}{h}\right)
$$

であるから，最大応力の略算式として，

$$
\begin{aligned}
\tau_{\max } & =1.5\left\{\frac{20}{27} \times \frac{h(l-a)}{l} \times \frac{1}{Q_{R}+Q_{L}} \times\left(\frac{Q_{R}}{C_{R}}+\frac{Q_{L}}{C_{L}}\right)\right. \\
& \left.-\frac{2}{3} \frac{a}{l}\right\} \tau_{0}
\end{aligned}
$$

が得られる。

この式に空の大きい $\mathrm{B}_{2}$ の場合を入れると $1.60 \tau_{0}$ とな る。精算値は $1.58 \tau_{0}$ であるから $2 \%$ の誤差である。
なお，梁のせん断力が断面積比に比例すると仮定する と, 上式は

$$
\tau_{\text {max }} \doteqdot 1.5\left\{\frac{20}{27} \times \frac{h(l-a)}{l} \times \frac{2}{C_{R}+C_{L}}-\frac{2}{3} \frac{a}{l}\right\} \tau_{0}
$$

となる。 $\mathrm{B}_{2}$ についてはり $2 \%$ の誤差である。

この例ではパネル部および梁の最大せん断応力は壁の それとほぼ等しい。

\section{5. まとめ}

壁梁断面が同一の時は梁を帯板とし，耐力壁断面が同 一の時は柱を帯板とし，二次元弾性により解を求めるこ とができる。

これら帯板に対する曲げ応力は，偪広い材ではその分 布が双曲線関数で表される。

以上による解は, 光弾性実験の結果とかなり一致する。 その結果，パネル部の最大せん断応力は，梁せいの小 さい場合は耐力壁の最大せん断応力を超える場合があ る。曲げ応力を直線分布と仮定した場合の最大せん断応 力は過大である。

補 記

旧論文注 1）によるパネル部の略算式にて, 縦方向の 力の和を求めているので, 横方向の柱からのせん断力に よる $Q / 2 l$ を差し引いているのは間違っていた。差引 がない方が正しい。ここに訂正いたします。

注

1）松井源吾 - 小川隆久「壁式構造における空の配置とせん 断応力分布に関する研究」日本建築学会諭文報告集, 第 286 号, pp. $00 \sim 00$, 昭和 54 年 12 月

2) G. Matsui, Y. Tsuboi : Stresses and Deformations at the Beam-to-Wall Joints of Shear Wall Structures, PhotoElastisity, (Proceedings of the International Symposium on Photoelasticity, Tokyo, 1986), Springer-Verlag

3) 建築学体系 9-1「建築弾塑性学」(彰国社, 昭和 43 年) p. 98

(1990年 9 月 6 日原稿受理, 1991 年 3 月 18 日採用決定) 